\title{
Comparative Studies On The Phytochemical Screening And In Vitro Antioxidant Activities Of Aqueous Extracts Of Garcinia Kola Stem And Root Barks
}

\author{
Philip O. Amira, Adebayo S. Daramola, Ayobioloja A. Philomina, and Salau A. Ibukun
}

\section{ABSTRACT}

\begin{abstract}
Phytochemicals are natural chemicals of plant origin that have implicated in anti-disease mechanism. Antioxidant are insulator of the process of the oxidation even at relatively small concentration and this have diverse physiological role in the body. They are naturally occurring in the medicinal plants, vegetables, leaves and roots that have defense mechanism and protect from various diseases as well inhibit, or delay the oxidation of other molecules by inhibiting the initiation or propagation of oxidizing chain reaction. Garcinia kola is a tropical flowering plant grown mainly in West and Central Africa. Garcinia kola is known for its anti-inflammatory and antioxidant properties. Therefore, comparative studies on the phytochemical screening and in vitro antioxidant activity on aqueous extracts of stem and root of Garcinia kola were investigated to assess their antioxidant properties in different antioxidant property determination assays. Aqueous extracts of Garcinia kola stem and root bark revealed the presence of tannins, resin, saponins, flavonoids, phenols, carbohydrates and alkaloids. In addition, the aqueous root bark extract of the plant contained phlobatanins and sterols while its stem bark aqueous extract contained terpenoids. The IC50 $(\mu \mathrm{g} / \mathrm{ml})$ values of the stem bark extract were $108.35 \pm$ 7.70, $122.81 \pm 3.98,0.20 \pm 0.01,0.16 \pm 0.01$ and $0.43 \pm 0.01$ for total antioxidant capacity (AAE), ferric reducing antioxidant activity (AAE), diphenyl picryl hydrazyl (DPPH) assay, nitric oxide (NO) scavenging activity and metal chelating activity respectively. On the other hand, the IC50 $(\mu \mathrm{g} / \mathrm{ml})$ values of the root bark extract were $31.54 \pm 2.72,30.50 \pm 0.96$, $2.26 \pm 0.13,4.36 \pm 0.52$ and $0.75 \pm 0.04$ for total antioxidant capacity (AAE), ferric reducing antioxidant activity (AAE), diphenyl picryl hydrazyl (DPPH) assay, nitric oxide (NO) scavenging activity and metal chelating activity respectively. Consequently, both the stem bark and root bark extracts generally exhibited remarkable in vitro antioxidant properties with respect to the parameters investigated.
\end{abstract}

Keywords: Phytochemical, Antioxidant, in vivo, Garcinia kola, medicinal.

\section{INTRODUCTION}

Phytochemicals can be defined as plant-derived chemicals, which are beneficial to human health and disease. In plants, phytochemicals repel harmful and attract beneficial organisms, serve as photo-protectants and exhibit appropriate response to environmental changes [1]. Phytochemicals are naturally occurring in the medicinal plants, vegetables, leaves and roots that have defense mechanism and protect from various diseases. In fact, phytochemicals (or antioxidants) such as nitrogen compounds (alkaloids, chlorophyll derivatives, amino acids and amines), phenolic compounds (tocopherols, flavonoids and phenolic acids), carotenoids and ascorbic acid [21], [36] inhibit, or delay the oxidation of other molecules by inhibiting the initiation or propagation of oxidizing chain reaction.

There is currently considerable interest in the antioxidant capacity of the human diet for its potential to prevent chronic
Published Online: June 11, 2020

ISSN: 2684-5199

DOI : $10.24018 /$ ejbio.2020.1.3.35

\section{Philip O. Amira}

The Federal Polytechnic, Nigeria.

The Federal Polytechnic, Nigeria.

(e-mail:success4daramola@gmail.com)

Ayobioloja A. Philomina

The Federal Polytechnic, Nigeria.

Salau A. Ibukun

The Federal Polytechnic, Nigeria.

*Corresponding Author
Adebayo S. Daramola*

diseases such as cancer, cardiovascular disease, diabetes and Alzheimer's disease [11], [25], [33], [38]. Epidemiological studies have shown that there is an inverse association between diet rich in fruits, vegetables, grains and nuts and chronic diseases [3], [6], [32]. Antioxidant compounds present in foods may help to protect cellular systems in the human body from oxidative damage and thus lower the risk of chronic diseases [30].

Reactive oxygen species (ROS) are constantly formed in the human body by normal metabolic action and these exert oxidative damaging effects by reacting with nearly every molecule found in living cells including nucleic acids, proteins, lipids or DNA and may involve in several chronic and degenerative diseases including gastritis, reperfusion injury of many tissues, atherosclerosis, ischemic heart disease, ageing, diabetes mellitus, cancer, immunosuppression, neurodegenerative diseases and others [39], [48] if excess ROS and free radicals are not eliminated 
by endogenous antioxidant system.

An antioxidant is a molecule capable of slowing or preventing the oxidation of other molecules. Synthetic antioxidants such as butylated hydroxytoluene (BHT), butylated hydroxyanisole (BHA), propylgallate (PG) and tertiary butyl-hydroquinone (TBHQ) are known to ameliorate oxidative damages but they have been restricted due to the carcinogenic and harmful effect on the lungs and liver [20]. Therefore, investigations of antioxidants are focused on naturally occurring substances, especially phytochemicals. Antioxidant compounds in food play an important role as a health protecting factor. Plant-sourced food antioxidants like vitamin $\mathrm{C}$, vitamin $\mathrm{E}$, carotenes, phenolic acids, phytate and phytoestrogens have been recognized as having the potential to reduce disease risk. Most of the antioxidant compounds in a typical diet are derived from plant sources and belong to various classes of compounds with a wide variety of physical and chemical properties. The main characteristic of an antioxidant is its ability to trap free radicals [50]. Garcinia kola (bitter kola) is a dicotyledonous plant belonging to the family of plants called Guttiferae. It is a perennial crop growing in the forest, distributed throughout West and Central Africa [27]. G. kola is also found distributed in the forest zone of Sierra purgative, anti-parasitic and antimicrobial properties. The seeds are used for bronchitis, throat Leone, Ghana, Cameroon and other West African countries. In Nigeria, it is common in the South Western States and Edo State [44]. It is a medium sized evergreen tree, about $15-17 \mathrm{~m}$ tall and with a fairly narrow crown. The leaves are simple, 6-14 cm long and 2-6 cm across, shiny on both surfaces and spotted with resin glands. The small flowers are covered with short, red hairs [27]. The fruit is a drupe of 5$10 \mathrm{~cm}$ in diameter and weighs $30-50 \mathrm{~g}$. Garcinia kola is traditionally used by African medicine men who believe that it has purgative, antiparasitic, and antimicrobial properties [28]. The seeds are used for bronchitis, throat infections, colic, head or chest colds, and cough. It is also used for liver disorders and as a chewing stick [28]. It is also used for liver disorders and as a chewing stick [16].

Recently attention has been paid to the possible health benefits of dietary phenolic phytochemicals that exhibit antioxidative, antibacterial, antiviral, anticarcinogenic, antiinflammatory and vasodilatory actions [9], [14]. The importance and health benefit of fruit and vegetable consumption in prevention of chronic diseases have been well documented. Consequently, comparative studies on the phytochemical screening and in vitro activity on aqueous extracts of stem and root bark of Garcinia kola were investigated to assess their antioxidant properties in different antioxidant property determination assays including Total antioxidant capacity (TAC), Ferric Reducing Antioxidant Property (FRAP), DPPH radical scavenging, Total Phenol, Total Flavonoids, NO scavenging activity and Metal chelating activity were studied in this report. Ascorbic acid, Garlic acid and EDTA were used as standards.

\section{MATERIALS}

\section{A. Collection of plant materials}

The leaves, stem and root bark of Garcinia kola were collected from Aba-Erinfun, Ado Local Government Area in Ado-Ekiti, Ekiti State, Nigeria. Identification of the sample took place at the Biochemistry Unit, Department of Science Technology, Federal Polytechnic Ado-Ekiti, Ekiti State, Nigeria.

\section{B. Chemicals used}

All the chemicals used were of analytical grade of BDH, Aldrich and Sigma Chemical Ltd., UK.

\section{METHODS}

\section{A. Preparation of extracts}

The fresh stem and root bark were air dried to obtain dry sample which was later ground first with mortar and pestle and thereafter, with a milling machine to obtain a fine powder. The ground powder in each case was dissolved in distilled water in a ratio of 1:20 (100 $\mathrm{g}$ in $2 \mathrm{~L}$ distilled water). This extraction took place in an extractor for 96 hours with regular stirring. The extract was obtained by filtering with Whatman filter paper and the filtrate freeze-dried in Armfield freeze-drier for 120 hours.

\section{B. Qualitative Phytochemical Screening}

Chemical tests were carried out on the aqueous extracts to determine the presence or absence of tannins, glycosides, resins, saponins, phlobatanins, flavonoids, sterols, phenols, carbohydrates, alkaloids and terpenoids using standard procedures as described by [22], [56], and [59].

\section{Determination of in vitro Antioxidant Activity of Aqueous Extracts of Garcinia kola stem and root bark}

\section{1. Determination of Total Antioxidant Capacity of Aqueous Extract of Garcinia kola stem and root bark}

The method described by Prieto et al. [47] was used. An aliquot of $0.1 \mathrm{~mL}$ sample solution containing a reducing species was combined with $1 \mathrm{~mL}$ of reagent solution $(0.6 \mathrm{M}$ sulphuric acid, $28 \mathrm{mM}$ sodium phosphate and $4 \mathrm{mM}$ Ammonium molybdate) in a test tube. The tubes were incubated in a water bath at $95{ }^{\circ} \mathrm{C}$ for 90 minutes. After the samples were cooled to room temperature, the absorbance of the aqueous solution was measured at $695 \mathrm{~nm}$ against a blank, which contained $1 \mathrm{~mL}$ reagent solution and $1.1 \mathrm{~mL} 80 \%$ methanol and incubated under the same conditions as the sample. The concentration of standard ascorbic acid used was $100 \mu \mathrm{g} / \mathrm{mL}$. The antioxidant activity of the sample was measured as ascorbic acid equivalent (AAE).

\section{2. Ferric Reducing Antioxidant Property Assay (FRAP) of Aqueous Extract of Garcinia kola stem and root bark}

The method of Benzie and Strain [5] was used. $300 \mathrm{mmol} / \mathrm{L}$ acetate buffer of $\mathrm{pH} 3.6,10 \mathrm{mmol} / \mathrm{L} \mathrm{2}$, 4, 6-tri(2-pyridyl)-1, 3, 5-triazine and $20 \mathrm{mmol} / \mathrm{L} \mathrm{FeCl}_{3} .6 \mathrm{H}_{2} \mathrm{O}$ were mixed together in the ratio 10:1:1 respectively, to give the working FRAP reagent. A $50 \mu \mathrm{L}$ aliquot of the sample extract at $1 \mathrm{mg} / \mathrm{mL}$ was added to $1 \mathrm{~mL}$ of FRAP reagent in a semimicro plastic cuvette. Absorbance measurement was taken at $593 \mathrm{~nm}$ exactly 10 minutes after mixing using $50 \mathrm{~mL}$ of water as reference.

In standardizing, $50 \mu \mathrm{L}$ of the standard $\left(\mathrm{FeSO}_{4} \cdot 7 \mathrm{H}_{2} \mathrm{O}\right.$, $1 \mathrm{mmol} / \mathrm{L}$ ) was added to $1 \mathrm{~mL}$ of FRAP reagent. All 
absorbance were taken at room temperature with samples protected from direct sunlight.

\section{3. DPPH Free Radical Scavenging Assay of Aqueous Extracts of Garcinia kola stem and root bark}

The method proposed and described by Blois [7] was used to determine the hydrogen radical scavenging properties of the extracts using the stable radical DPPH (2, 2-Diphenyl-1picrylhydrazyl hydrate). $1 \mathrm{~mL}$ of $0.3 \mathrm{mM}$ DPPH in methanol was added to $1 \mathrm{~mL}$ of varying concentrations $(0.1,0.05$, $0.0025,0.0125,0.00625,0.003125 \mathrm{~g} / \mathrm{mL}$ ) of the sample extract and allowed to react. The mixture was thoroughly mixed and incubated in a dark cupboard for 30 minutes after which the absorbance was measured at $517 \mathrm{~nm}$ against a DPPH negative control containing only $1 \mathrm{~mL}$ of methanol in place of the sample. Distilled water was used as a blank. Ascorbic acid was used as standard.

\section{4. Determination of Concentration of Total Phenols in aqueous extracts of Garcinia kola stem and root bark}

The total phenolic content was determined using the method described by Singleton and Rossi [55] using FolinCiocalteu's phenol reagent. Briefly, $0.9 \mathrm{~mL}$ of distilled water was added to $0.1 \mathrm{~mL}$ of $1 \mathrm{mg} / \mathrm{mL}$ of the extract. Then $0.2 \mathrm{~mL}$ of Folin-Ciocalteu's phenol reagent was added and reacting mixture was vortexed. After 5 minutes, $1 \mathrm{~mL}$ of $7 \%(\mathrm{w} / \mathrm{w})$ $\mathrm{Na}_{2} \mathrm{CO}_{3}$ solution was added to the mixture. The solution was then diluted to $2.5 \mathrm{~mL}$ and then incubated for 90 minutes at room temperature. The absorbance of the resulting product formed at $750 \mathrm{~nm}$ was then read against a negative control containing $1 \mathrm{~mL}$ of methanol in place of the sample. Reading was compared to that of the standard Gallic acid equivalent (GAE) of sample, after preparing a calibration curve. Distilled water was used as a blank.

\section{5. Determination of Flavonoids Concentration in aqueous extracts of Garcinia kola stem and root bark}

The method of Boham and Kocipal-Abyazam [8] was used to determine the flavonoid concentration. About $0.25 \mathrm{~g}$ of the sample was extracted repeatedly with $100 \mathrm{~mL}$ of $80 \%$ aqueous methanol at room temperature. The whole solution was filtered through Whatman filter paper no. $42(125 \mathrm{~mm})$. The filtrate was later transferred into a crucible and evaporated to dryness on a water bath and weighed to a constant weight.

\section{6. Nitric Oxide (NO) Scavenging Assay of Aqueous Extract of Garcinia kola stem and root bark}

The method of Garrat [18] was used. The reaction mixture contained $10 \mathrm{mM}$ sodium nitroprusside, phosphate buffered saline ( $\mathrm{pH} 7.4$ ) and various concentrations $(0-70 \mu \mathrm{g} / \mathrm{mL})$ of the test solution in a final volume of $3 \mathrm{~mL}$. After incubation for 150 minutes at $25{ }^{\circ} \mathrm{C}, 1 \mathrm{~mL}$ sulphanilamide $(0.33 \%$ in $20 \%$ glacial acetic acid) was added to $0.5 \mathrm{~mL}$ of the incubated solution and allowed to stand for 5 minutes. Then $1 \mathrm{~mL}$ of naphthylethylenediamine dihydrochloride (NED) $(0.1 \% \mathrm{w} / \mathrm{v})$ was added and the mixture incubated for 30 minutes at $25 \mathrm{oC}$.

The pink chromophore generated during diazotization of nitrite ions with sulphanilamide and subsequent coupling with NED was measured spectrophotometrically at $540 \mathrm{~nm}$ against a blank sample. All tests were performed in triplicates. Ascorbic acid was used as a standard.

\section{7. Determination of Metal Chelating Activity of Aqueous Extracts of Garcinia kola stem and root bark}

The chelating of ferrous ions is estimated using the method of Dinis et al. [13]. Briefly, $0.1 \mathrm{~mL}$ of the extract was added to $0.5 \mathrm{~mL}$ of $0.2 \mathrm{mM}$ ferrous chloride solution. The reaction was initiated by the addition of $0.2 \mathrm{~mL}$ of ferrozine $(5 \mathrm{mM})$ and incubated at room temperature for 10 minutes and then the absorbance was measured at $562 \mathrm{~nm}$. Ethylene di-amine tetra acetic acid (EDTA) was used as the standard

\section{Statistical Analysis}

All values were expressed as the mean of five determinations \pm S.E.M.

\section{RESUlTS}

Phytochemical screening of the aqueous extracts of stem and root bark of Garcinia kola revealed the presence of tannins, resins, saponins, flavonoids, phenols, carbohydrates and alkaloids. In addition, the aqueous extract of stem bark showed the presence of terpenoids while the root bark aqueous extract also contained phlobatanins and steroids (Table I). However, glycosides were not detected in any of the samples tested.

Table II revealed that both the aqueous extract of stem and root bark of Garcinia kola exhibited remarkable in vitro antioxidant activity on the basis of the various parameters studied.

TABLE I: RESULTS OF SOME PHYTOCHEMICALS SCREENED IN AQUEOUS EXTRACT OF GARCINIA KOLA STEM AND ROOT BARKS

\begin{tabular}{lcc}
\hline Phytochemical & Stem bark & Root bark \\
\cline { 2 - 3 } Tannins & + & + \\
Glycosides & - & - \\
Resins & + & + \\
Saponins & + & + \\
Phlobatanins & - & + \\
Flavonoids & + & + \\
Sterols & - & + \\
Phenols & + & + \\
Carbohydrates & + & + \\
Alkaloids & + & + \\
Terpenoids & + & - \\
+ Present & &
\end{tabular}

\section{DISCUSSION}

In this study the presence of these metabolites suggests that the plant might be of medicinal importance [54]. The presence of these phytochemicals in the stem and root bark aqueous extract of Garcinia kola confers medicinal properties on the plant and this explains the use of this plant for treatment of different ailments. The finding of this study is similar to the report in [4] where among the phytochemicals present as reported in this study, only steroid was reported absent in the cited work. Also, the phytochemical screening carried out by [42] showed the presence of saponins and alkaloids as reported in the present study. The slight variation in the phytochemical composition could be as a result of presence of pathogens, preparation of sample, environmental factors such as temperature, pressure, chemicals and the reagent used for the analysis. 
TABLE II: IN VITRO ANTIOXIDANT ACTIVITIES OF AQUEOUS EXTRACTS OF GARCINIA KOLA STEM AND ROOT BARK

\begin{tabular}{|c|c|c|c|c|c|c|c|}
\hline \multirow{3}{*}{ Extract type } & \multicolumn{7}{|c|}{ Parameters } \\
\hline & $\begin{array}{c}\text { Total Antioxidant } \\
\text { Capacity (TAC) }\end{array}$ & $\begin{array}{c}\text { Ferric reducing } \\
\text { antioxidant } \\
\text { (FRAP) }\end{array}$ & $\begin{array}{l}\text { DPPH free } \\
\text { radical } \\
\text { Scavenging }\end{array}$ & $\begin{array}{c}\text { Total Phenol } \\
\text { (GAE) }\end{array}$ & $\begin{array}{l}\text { Flavonoids } \\
\text { (GAE) }\end{array}$ & $\begin{array}{c}\text { Metal } \\
\text { Chelating }\end{array}$ & Nitric oxide \\
\hline & $\begin{array}{c}\text { Ascorbic Acid } \\
\text { Equivalent }\end{array}$ & \multicolumn{6}{|c|}{$\mathrm{IC}_{50}$ Values $(\mu \mathrm{g} / \mathrm{mL})$} \\
\hline Stem bark & $108.35 \pm 7.70$ & $122.81 \pm 3.98$ & $0.20 \pm 0.01$ & $169.04 \pm 11.87$ & $156.65 \pm 8.37$ & $0.43 \pm 0.01$ & $0.16 \pm 0.01$ \\
\hline Root bark & $31.54 \pm 2.72$ & $30.50 \pm 0.96$ & $2.26 \pm 0.13$ & $193.26 \pm 7.05$ & $37.48 \pm 1.82$ & $0-.75 \pm 0.04$ & $4.36 \pm 0.52$ \\
\hline \multicolumn{8}{|c|}{ Standards } \\
\hline Ascorbic acid & - & - & $0.10 \pm 0.01$ & - & - & - & $0.10 \pm 0.01$ \\
\hline $\begin{array}{l}\text { Ethylene diamine tetra } \\
\text { acetic acid (EDTA) }\end{array}$ & - & - & - & - & - & $\begin{array}{c}0.02 \pm \\
2.56 \mathrm{E} 05\end{array}$ & - \\
\hline
\end{tabular}

Values are means of five determinations + S.E.M

Presence of these secondary metabolites may contribute to its antioxidant and pharmacological potentials. Adequate knowledge of the chemical constituents of plants is desirable because such information will be valuable for synthesis of complex chemical substances and to screen for biological activities [34].The phenols and flavonoids are widely distributed secondary metabolites in plants having antioxidant activity and wide range of biological activities such as anti-apoptosis, anti-aging, anti-carcinogen, antiinflammation, anti-atherosclerosis, cardiovascular protection and improvement of endothelial function, as well as inhibition of angiogenesis and cell proliferation activities [49].

Specifically the presence of phenolic compounds provides pharmacological activities like; anti-cancer [31], [37], antioxidant [31], [45], anti-microbial [24], [53], wound-healing [40] and anti-inflammatory [45], that may suggest an association to the specie here investigated. The total phenol serves as a pointer to efficient antioxidant property of the extracts. Phenols form a wide group of natural antioxidants present in a large number of plant foods. They contribute to food characteristics such as taste, colour or shelf-life. They also participate in the prevention of several major chronic diseases such as cardiovascular diseases, diabetes, cancers or neurodegenerative diseases [41] whose pathogenesis have been linked to the action of free radicals.

The total flavonoid reported in this study is similar to the one reported in [2] in Garcinia kola seed thus showing that the plant has a strong and high store of secondary metabolites of medical benefits. Flavonoids are polyphenolic compounds known for their high antioxidant properties and free radical scavenging ability [52]. Studies have revealed that consumption of flavonoid-rich foods and plants could help in the management of hypertension [35]. They may also prevent the progressive impairment of pancreatic cells function due to oxidative stress and thus reduce the occurrence of type 2 diabetes [57]. This result was also consistent with the order of total phenol content of each extract. Several studies have reported the relationship between phenolic content and antioxidant activity. In [43] and [60] reported a strong relationship between total phenolic content and antioxidant activity in selected fruits, vegetables and grain products.

The antiradical activity of phenolics is majorly based on the redox properties of their hydroxyl groups and the structural relationships between different parts of their chemical structure [49]. The DPPH free radical scavenging ability result revealed that the extracts were able to effectively inhibit DPPH radicals at a high level with increasing percentage inhibition at increasing concentrations.

The $\mathrm{Fe}^{2+}$ chelating ability revealed that the extracts of Garcinia kola were able to chelate $\mathrm{Fe}^{2+}$ at the concentration of the extract tested. The mechanism by which iron can cause its deleterious effect is that $\mathrm{Fe}^{2+}$ can react with hydrogen peroxide $\left(\mathrm{H}_{2} \mathrm{O}_{2}\right)$ to produce hydroxyl radical $(\mathrm{OH})$ via the Fenton reaction, whereas superoxide can react with $\mathrm{Fe}^{3+}$ to regenerate $\mathrm{Fe}^{2+}$ that can again participate in the Fenton reaction [17]. Hence, potent iron chelators are desirable in preventing iron from initiating free radical generation via the Fenton reaction.

Nitric oxide is an important chemical mediator generated by endothelial cells, macrophages, neurons etc. and is involved in the regulation of various physiological process [51]. Nitric oxides formed during their reduction with oxygen or with superoxides such as $\mathrm{NO}_{2}, \mathrm{~N}_{2} \mathrm{O}_{4}, \mathrm{~N}_{3} \mathrm{O}_{4}$ are very reactive. Nitrite ions react with Griess reagent and form a purple azo-dye. The decrease in the formation of purple azo dye reflects the presence of scavengers in the test compound. The aqueous extracts of the stem and root bark of Garcinia kola was found to be a good scavenger of nitric oxide radicals in sodium nitroprusside thereby showing the high potency of the extract to exert its inhibitory effect on Nitric Oxide at very low concentrations.

Transition metals are reported to play part in the generation of free radical [19]. Transition elements such as iron and copper are capable of fronting free radical generation because they are catalysts due to lone pair of electrons on their outermost shell [15]. As a result, they become structurally unstable and often orchestrate the conversion of $\mathrm{H}_{2} \mathrm{O}_{2}$ to $\mathrm{OH}$ in the Fenton Reaction [25]. Antioxidant compounds have the capacity to chelate and bond free radicals into forms that can easily be removed from the body. This property of antioxidant compounds are due to their redox properties which allow them to act as reducing agents, electron donor, oxygen quenchers or metal chelators [12], [46]. In the present study, the extracts chelate metals efficiently at a relatively lower concentration.

\section{CONCLUSION}

Aqueous extract of the stem bark of Garcinia kola contained tannins, resin, saponins, flavonoids, phenols, carbohydrates, alkaloids and terpenoids. On the other hand, 
the aqueous extract of the plant's root bark contained tannins, resin, saponins, phlobatanins, flavonoids, steroids, phenols, carbohydrates and alkaloids. However, none of the extracts contained glycosides. Furthermore, both extracts exhibited remarkable in vitro antioxidant activities with respect to the various parameters studied.

\section{REFERENCES}

[1] Anderson G. D. (2004): Phytochemicals. Dynamic Chiropractic, 2(1):1-2.

[2] Adedayo, B. C., Ademiluyi, A. O., Oboh, G. and Akindahunsi, A. A. (2013): Interaction of aqueous extracts of two varieties of yam tubers (Dioscorea spp) on some key enzymes linked to type 2 diabetes in vitro. International Journal of Food Sciences \& Technology, 47: 703-709.

[3] Adom, K. K. and Liu, R. H. (2002): Antioxidant Activity of Grains. Journal of Agricultural and Food Chemistry, 50: 6182-6187.

[4] Antwi-Boasiako C.and Abubakari A. (2011): Anti-microbial and phytochemical propetires of crude extract of Garcinia kola Heckel stems used for oral health. Research Journal of Pharmacology, 5(5): 6876.

[5] Benzie, F. F. and Strain, J. J. (1999): Ferric Reducing/ Antioxidant Power Assay: Direct Measure of Total antioxidant Activity of Biological Fluids and Modified Version for Simultaneous Measurement of Total Antioxidant Power and Ascorbic Acid Concentration. Methods in Enzymology, 299: 15-23.

[6] Block, G., Patterson, B. and Subar, A. (1992): Fruit, vegetables, and cancer prevention: a review of the epidemiological evidence. Nutrition and Cancer-An International Journal, 18(1): 1-29.

[7] Blois, M. S. (1958): Antioxidant determination by the use of a stable free radical. Nature, 181: $1199-1200$

[8] Boham, B. A. and Kocipal-Abyazam, R. (1994): Flavonoids and Condensed Tannins from Leaves of Hawaiian Vaccinium vaticulatum and V. calycinium. Pacific Science; 48: 458 - 463.

[9] Breinholt, V. (1999): Desirable versus harmful levels of intake of flavonoids and phenolic acids. Natural Antioxidants and Anticarcinogens in Nutrition, Health and Disease. Eds J. Kumpulainen and J.E. Salonen. The Royal Society of Chemistry, Cambridge. 37: 190-197.

[10] Chandrasekara, N. and Shahidi, F. (2011): Effect of Roasting on Phenolic Content and Antioxidant Activities of Whole Cashew Nuts, Kernels, and Testa. Journal of Agricultural and Food Chemistry.59: 5006-5014.

[11] Christen, Y. (2000): Oxidative stress and Alzheimer's disease. American Journal of Clinical Nutrition, 71: 621S-629S.

[12] Demiray, S., Pintado, M. E. and Castro, P. M. L. (2009): Evaluation of Phenolic Profiles and Antioxidant Activities of Turkish Medicinal Plants: Tilia rrgentea, Crataegi folium Leaves and Polygonum bistorta Roots"'. World Academy of Science, Engineering and Technology. 54: 312-317.

[13] Dinis, T. C. P., Maideira, V. M. C and Almeida, L. M (1994): Actions of phenolic derivatives (Aceto aminophan, salycilate and 5aminosalycilate) as inhibitors of membrane lipid peroxidation and as peroxyl radical scavengers. Archives of Biochemistry and Biophysics. 315:161-169.

[14] Duthie, G. G., Duthie, S. J. and Kyle, J. A. M. (2000). Plant polyphenols in cancer and heart disease: Implications as nutritional antioxidants, Nutrition Research Reviews, 13: 79-106.

[15] Ekaluo U. B., Ikpeme, E. V., Uno, U. U., Umeh, S. O and Erem, F A (2015): Protective role of Aqueous Guava leaf extract against caffeine induced spermatotoxicity in Albino rats. Research Journal of Medicinal Plants, 10: 98-105.

[16] Farombi E. O, Adepoju B. E, Ola-Davies O. E. and Emerole, G. O (2005): Chemeo prevention of aflatoxin induced genotoxicity and hepatic oxidative demage in rat by kolaviron, a natural bioflavonoid of Garcinia kola seeds. European Journal of Cancer Prevention, 14: $207-$ 214.

[17] Fraga, C. G. and Oteiza, P. I. (2002): Iron toxicity and antioxidant nutrients. Toxicology, 180:23-32.

[18] Garratt, D. C. (1964): The Quantitative Analysis of Drugs, Springer Boston, USA, pp 62-67.

[19] Ghimeray A. K., Jin C., Ghimine B. K. and Cho, D. H (2009): Antioxidant activity and quantitative estimation of azadirachtin and nimbin in Azadirachta indica A. Juss grown in foothills of Nepal. African Journal of Biotchnology, 8: 3084-3091.

[20] Gokhan, Z., Abdurrahman, A., Gokalp, O. G., Yavuz S. C. and Evren, Y. (2011): Antioxidant Properties of Methanolic Extract and Fatty acid
Composition of Centaurea urvillei DC. Subsp. Hayekiana Wagenitz. Records of Natural Products, 5: 123-132.

[21] Hall, C. A. and Cuppet, S. L. (1997): Activities of Natural antioxidants. In: Aruoma, O. I. and Cuppet, S. L. (Eds.), Antioxidant Methodology in vivo and in vitro Concepts. AOCS Press, Champaign, II, pp. 2-20.

[22] Harborne, J. B. (1983): Phytochemical Methods. A Guide To Modern Techniques Of Plant Analysis. 3rd Edn., Chapman and Hall Publishing, London, United kingdom, p 67.

[23] He, Z., Fu, M. and Mao, L. (2011): Total phenolic and condensed tannin and antioxidant activity of four Caryaspecies from China. African Journal of Biotechnology, 10(51): 10472-10477.

[24] Hendra, R., Ahmad, S., Sukari, A., Shukor M.Y and Oskoueian E (2011): Flavonoid Analysis and Antimicrobial Activity of Various Parts of Phaleria Macrocarpa (Scheff.)Boerl Fruit. International Journal of Molecular Sciences, 12: 3422-3431.

[25] Hsu C.Y., Chan Y. P and Chang J (2006): Antioxidant activity of extract from Polygonum cuspidatum. Biological Research, 40: 13-21.

[26] Hu, F. B. (2003): Plant-based foods and prevention of cardiovascular disease: an overview. American Journal of Clinical Nutrition, 78: 544S-551S.

[27] Iwu, M. M. (1993): Handbook of African Medicinal Plants, CRC Press, London, pp. 183-184.

[28] Iwu, M. Duncan A. R. and Okunji C. O. (1999): New Antimicrobials of Plant Origin, ASHS Press, Alexandria, VA, p. 457-462.

[29] Jaiswal, Y. S., Tatke, P. A., Satish, Y.G. and Ashok, V. (2010): Antioxidant Activity of Various Extracts of Leaves of Anacardium occidentale (Cashew). Research Journal of Pharmaceutical, Biological and Chemical Sciences, 1(4):.113

[30] Kaur, C. and Kapoor, H. C. (2001): Antioxidant in fruits and vegetables - the millennium's health. International Journal of Food Science and Technology, 36: 703-725.

[31] Khacha-Ananda S., Tragoolpua K., Chantawannakul P and Tragoolpua Y. (2013): Antioxidant and Anti-Cancer Cell Proliferation Activity of Propolis Extracts From Two Extraction Methods. Asian Pacific Journal of Cancer Prevention, 14: 6991-6995.

[32] Knekt, P., Kumpulainen, J., Jarvinen, R., Rissanen, H., Heliovaara, M., Reunanen, A., Hakulinen, T., and Aromaa, A. (2002): Flavonoid intake and risk of chronic diseases. American Journal of Clinical Nutrition, 76: 560-568.

[33] Kris-Etherton, P. M., Hecker, K. D., Bonanome, A., Coval, S. M., Binkoski, A. E., Hilpert, K. F., Griel, A. E., and Etherton, T. D. (2002): Bioactive compounds in foods: their role in the prevention of cardiovascular disease and cancer. American Journal of Medicine, 113:71S-88S.

[34] Kumari, M. (2003): Phytochemical screening and antioxidant activity of in vitro grown plants Clitoria ternatea L Using DPPH assay. Asian Journal of Pharmaceutical and Clinical Research, 6(2): 38-42.

[35] Kwon Y. I., Vattem, D. A. and Shetty, K. (2006): Evaluation of clonal herbs of Lamiaceae species for management of diabetes and hypertension, Asia Pacific Journal of Clinical Nutrition, 15:107-118.

[36] Larson, R. A (1988): The antioxidants of higher plants. Phytochemistry, 27: 969-978.

[37] Lin, Y., Shi, R.., Wang, X. and Shen, H. M. (2008): Luteolin, A Flavonoid with Potential for Cancer Prevention and Therapy. Current Cancer Drug Target, 8(7): 634-646.

[38] Liu, R. H. (2003): Health benefits of fruit and vegetables are from additive and synergistic combinations of phytochemicals. American Journal of Clinical Nutrition, 78: 517S-520S.

[39] Narendra V., Mukul T., and Narayan P. G. (2010): Antioxidant Potential of Psidium Guajava Linn. International Journal Pharmacy and Technology Research, 2: 417-419.

[40] Nayak, B. S.and Pinto, P. L. M. (2006). Catharanthus roseus Flower Extract has Wound-Healing Activity in Sprague Dawley Rats. BMC Complement Alternative Medicine, 6: 41

[41] Neveu, V., Perez-Jiménez, J., Vos, F., Crespy, V., Du Chaffaut, L., Mennen, L., Knox, C., Eisner, R., Cruz, J., Wishart, D. and Scalbert, A. (2010): Phenol-Explorer: an online comprehensive database on polyphenol contents in foods. Database, doi: 10.1093/database/bap024 (Version 1.5.2, available at http:// www.phenol-explorer.eu).

[42] Obuekwe I. F. and Onwukaeme N. D. (2004): Phytochemical analysis and anti-microbial activities of the leaf and stem bark extracts of Garcina kola- Herkel (Family Gultiferae). Pakistan Journal of Scientific Research, 47(2): 160-162

[43] Odukoya, O. A, Jenkins, M. O, Ilori, M. O. O and Sodifiya, M. O. (2005): The use of selected Nigerian natural products in management of environmentally induced skin damage. Pakistan Journal of Biological Sciences, 8: 1074-1077.

[44] Otor, J, U., Abdulkadir, U, and Abu, M. A. (2001): Some biological activities of Garcinia kola in growing rats. Veterinary Archives, 71(5): 287-297. 
[45] Pourmorad F., Hosseinimehr S.J and Shahabimajd N. (2006): Antioxidant Activity, Phenol and Flavonoid Content of Some Selected Iranian Medicinal Plants. African Journal of Biotechnology, 5(11): 1142-1145

[46] Premanath, R. and Lakshmidevi, N. (2010): Studies on anti-oxidant activity of Tinospora cordifolia (Miers.) leaves using in vitro models. Journal of American Sciences, 6:736-743.

[47] Prieto, P., Pineda, M. and Aguilar, M. (1999): Spectrophotometric quantitation of antioxidant capacity through the formation of a Phosphomolybdenum Complex: Specific application to the determination of vitamin E. Analytical Biochemistry, 269: 337-341.

[48] Raghavendra, H. Lakshmanashetty, Y. B., Nagaraj, M. G. H and Vadlapudi, K. (2010): In vitro Antioxidant Activity of Vitex negundo L. Leaf Extracts. Chiang mai Journal of Sciences, 37: 489-497.

[49] Rice-Evans, C., Miller, N. and Paganga, G. (1996): Structureantioxidant activity relationships of flavonoids and phenolic acids. Free Radical Biology and Medicine, 21(3): 417

[50] Rumit, S., Heena, K., Rajal, S. and Naveen, S. (2010): In vitro Antioxidant Activity of Roots of Tephrosia Purpurea Linn. International Journal of Pharmacy and Pharmaceutical Sciences, 2: 3033.

[51] Saurabh G., Kumar M., Duraiswamy M. and Atika, C.(2012): In vitro antioxidant and Free radical scavenging activities of Ocimum sanctum. World Journal of Pharmaceutical Research, 1(1): 78-94.

[52] Scherer, R. and Godoy, H. (2009): Antioxidant activity index (AAI) by the 2,2- diphenyl-1-picrylhydrazyl method. Food Chemistry. 112: 654658.

[53] Sengul, M., Yildiz, H., Gungor, N., Cetin, B., Eser, Z. and Ercisli, S. (2009): Total Phenolic Content, Antioxidant and Antimicrobial Activities of Some Medicinal Plants. Pakistan Journal of Pharmaceutical Sciences, 22(1): 102-106.

[54] Shobana, G., Keerthana, K., Dr., Agnel A. J., Edwina, A. and Sherley, F. (2015): In vitro antioxidant potentials of aqueous extract of Anacardium occidentale 1. World Journal of Pharmacy And Pharmaceutical Sciences, 5(1): 1458-1467.

[55] Singleton, V. L. and Rossi, J. A., Jr. (1965): Colorimetry of total phenolics with phosphomolybdic- phosphotungstic acid reagents. American Journal of Enology and Viticulture, 16: 144-158

[56] Sofowora, A. (1989): Screening for Bioactive Agents. In: Medicinal Plants And Traditional Medicine In Africa, 2nd Ed., Spectrum Books Limited, Ibadan, Nigeria, pp 134-156.

[57] Song, Y., Mauson, J. E., Buring, J. E., Sesson, H. D. and Liu, S. (2005): Association of dietary flavonoids with risk of type 2 diabetes, and markers of insulin resistance and systemic inflammation in women: A prospective study and cross sectional analysis. Journal of the American College of Nutrition, 24(5):376-384.

[58] Tiwari P., Kumar B., Kaur M., Kaur G. and Kaur K. (2011) Phytochemical screening and extraction: A review. Internationale Pharmaceutica Sciencia, 1(1): 98-106.

[59] Trease, G. E. and Evans, W. C (1985). Pharmacognosy (11edn). English Language, The Book Society, Bailliere Tindall, Britain, pp 45 50 .

[60] Velioglu, Y. S., Mazza, G., Gao, L., and Oomah, B. D, (1998): Antioxidant activity and total phenolics in selected fruits, vegetables and grain products. Journal of Agriculture and Food Chemistry, 46: 4113-4117. 